House, Piccadilly, London, on December 15. The inaugural meeting of this newly established association was referred to in Nature of July 24, 1937, p. 163. At its inception, 53 biologists joined the Association, and since then the membership has increased to 162. The aims of the Association, among others, are : to study the bases and practical aims of taxonomy; to examine criteria employed in defining species and other systematic categories; to consider any modification of existing classification in the light of eytogenetic, ecological, physiological, embryological, biochemical and palæontological data ; to press for increased attention to taxonomy in museums and other institutions; to organize research; to aid the production of handbooks on British animals and plants, and eventually to produce a British Fauna and Flora on uniform biological lines; to investigate methods of teaching systematics; to promote co-operation between workers in different branches of biology on problems of taxonomic interest. The Taxonomic Principles Committee has already considered several important problems, and has decided to prepare an index of all terms which have been used to designate groups below the rank of species. This should prove of value, especially to young research workers in taxonomy. The Committee on Comparative Systematics has examined the sources from which data for research on variability and other problems may be drawn. The Research Committee has initiated or assisted in the launching of twelve lines of research, and a list of institutions where such work may be done has been prepared. Work has been started on a book on the anatomy of Dicotyledons. The Committee on Handbooks is now compiling a review of existing taxonomic literature on the British flora and fauna. The provision of a check list of the British flora and fauna is being dealt with in collaboration with the Association of British Zoologists. Cheap systematic handbooks are also being considered.

The Committee for Co-ordinating the Work of Natural History Societies has been aided in its exacting task by the British Association. The pioneer work of these various committees is commendable, and all biologists, whether directly interested in systematics or not, will be grateful for the results of their work. Various publications, such as articles in NATURE and Chronica Botanica, have been sponsored by the Association, and others are projected. Discussions and symposia on taxonomic subjects have been supported by the Association at meetings of the British Association and of the Linnean, Zoological and Genetical Societies. The Association has no constitution yet, but it has since worked with enthusiasm. It is considered that with a minimum membership of five hundred, each member paying the modest sum of $£ 1$ for lifemembership, the Association could achieve all its aims. We hope that this enro'ment will be achieved and even exceeded, for the Association has, in a very short time, showed that it is providing an essential service to biology, and considering its present projects, its usefulness will certainly continue to increase. Not only specialized systematists but also all other biologists would prove useful to this Association, which clearly deserves all the support it can get. Information concerning the Association can be obtained from either Mr. J. S. L. Gilmour, Royal Botanic Gardens, Kew, Surrey, or Mr. H. W. Parker, British Museum (Natural History), South Kensington, London, S.W.7.

\section{Palæolithic Finds in Bulgaria}

Dr. Dorothy Garrod's account of her recent excavation of the cave of Batcho Kiro, near Drevono, in Bulgaria, given before the Society of Antiquaries of London on December 8, adds a link of no little importance to the chain of evidence of the distribution of cultures of the later periods of the palæolithic age in eastern Europe and adjacent regions. Dr. Garrod's excavations were carried out in the summer of 1938 , when she had the assistance of $\mathrm{Mr}$. James Gaul and Mr. Bruce Howe of Harvard University, by permission of the Bulgarian Government and with the cooperation of the National Museum of Sophia. The cave is very large with an intricate system of corridors running at least a kilometre into the rock. Flint implements had already been discovered here in association with bones of the cave bear by a local engineer. The present excavations were confined in the main to the principal chamber; and here for the first time in Bulgaria a stratified sequence of palæolithic deposits has been found. At the bottom of the section was a Mousterian level, in which the implements were made chiefly from pebbles of volcanic rock from a stream near by. Above this level were layers of deposits belonging to the Upper Palæolithic, in which the industries were more or less of Aurignacian type, and the implements were made of flint. They were associated with animal bones, among which were cave bear, cave hyena, and in the lowest levels woolly rhinoceros. These levels, corresponding to others of the same kind in other parts of Europe, are to be assigned to the last stage of the Quaternary Ice Age.

\section{Prehistoric "Harpoon" from Scotland}

A REMARKABLE barbed point of red deer antler found in the bed of the River Irvine below Shewalton Sands, Ayrshire, was described by Mr. A. D. Lacaille at a meeting of the Society of Antiquaries of Scotland in Edinburgh on December 12. The point, which may have been part of a harpoon or multi-pronged fish-spear, is believed to be the largest prehistoric point of its kind as yet recorded in the British Isles. It measures $75 \frac{5}{8}$ inches long, and is rhombic in section. It has five pairs of barbs. A groove appears on each side of a pronounced mid-rib at the tip. It has been skilfully fashioned, evidently by stone tools. The dating of the point is uncertain ; but it is conjectured that it was made by settlers on Shewalton Moor, a locality rich in prehistoric and other antiquities. Both its form in section and the grooves mark a considerable technical advance on the Azilian type of barbed harpoon. Nevertheless, the Shewalton point, it is indicated, bears a general resemblance 